\title{
Source of Aegean Sea harbour porpoises
}

\author{
Patricia E. Rosel ${ }^{1, *}$, Alexandros Frantzis ${ }^{2}$, Christina Lockyer ${ }^{3}$, Anastasia Komnenou ${ }^{4}$ \\ ${ }^{1}$ National Marine Fisheries Service, 219 Fort Johnson Road, Charleston, South Carolina 29412, USA \\ ${ }^{2}$ Pelagos Cetacean Research Institute, Terpsichoris 21, 16671 Vouliagmeni, Greece and National Centre for Marine Research, \\ Agios Kosmas, 16604 Hellenikon, Greece \\ ${ }^{3}$ Danish Institute for Fisheries Research, Charlottenlund Slot, 2920 Charlottenlund, Denmark \\ ${ }^{4}$ Clinic of Surgery, Faculty of Veterinary Medicine, Aristotle University of Thessaloniki, St Voutyra 11, 54627 Thessaloniki, Greece
}

\begin{abstract}
Documented sightings of harbour porpoises in the Mediterranean are rare, although the species is common in the neighbouring North Atlantic and Black Sea. However, in the past 2 decades, 4 harbour porpoises Phocoena phocoena have been recorded in the northern Aegean Sea in the eastern Mediterranean Basin. Samples were taken from 2 of these. Both have a genetic signature indicative of the Black Sea and their age and small size further suggest they originated from the Black Sea rather than the Atlantic population. These results are the first to indicate probable movement of porpoises out of the Black Sea and into the Mediterranean Sea.
\end{abstract}

KEY WORDS: Phocoena $\cdot$ Genetic identification $\cdot$ Mediterranean $\cdot$ Mitochondrial DNA Resale or republication not permitted without written consent of the publisher

\section{INTRODUCTION}

The distribution of the harbour porpoise Phocoena phocoena is somewhat of a biogeographic conundrum. This species is circum globally distributed in coldtemperate waters of the Northern Hemisphere but is also present in the Black Sea. Two other cetacean species found in the Black Sea, Tursiops truncatus and Delphinus delphis, are also present in the Mediterranean Sea. The harbour porpoise, on the other hand, is extremely rare in the Mediterranean basin, both historically and in the present day. Frantzis et al. (2001) summarized the historical records of this species in the Mediterranean and concluded that most of these records are poorly documented and do not provide equivocal support for a historical population of harbour porpoises in the Mediterranean basin. Only 5 records (Table 1), all in the last 2 decades, are sufficiently well documented to provide unequivocal evidence of the species' presence in the Mediterranean (Frantzis et al. 2001). Of these 5 records, 4 are for the northern Aegean Sea (see Fig. 1), and they raise the question as to whether these porpoises form a small, isolated, and therefore extremely vulnerable population of harbour porpoises unique to the Aegean Sea or whether these recent individuals have come from somewhere else, namely the Black Sea or the Atlantic Ocean, 2 habitats which support harbour porpoise populations.

Both genetic (Rosel et al. 1995) and morphological (Tsalkin 1938, Kleinenberg 1956) data suggest that Black Sea and Atlantic populations of harbour porpoises are reproductively isolated from each other. No mitochondrial DNA (mtDNA) sequences from the control region were shared between porpoises collected in the Black Sea and those collected in the North Atlantic (Rosel et al. 1999b). Tsalkin (1938) found that adult porpoises from the Black Sea were smaller, weighed less and had smaller skulls. Thus, both genetic and morphological evidence suggests that these populations are well differentiated. If this is the case, can we use genetic and morphological data to identify the source of porpoises found in the Aegean Sea in the last few decades?

\section{MATERIALS AND METHODS}

Skin samples were collected from 2 beachcast male Phocoena phocoena found in Apalos Bay $\left(40^{\circ} 50^{\prime} 35^{\prime \prime} \mathrm{N}\right.$, $25^{\circ} 56^{\prime} 00^{\prime \prime} \mathrm{E}$ ) in the northeastern Aegean Sea (Fig. 1) in February and March of 2000, respectively (Frantzis et al. 2001). DNA was extracted from these samples 


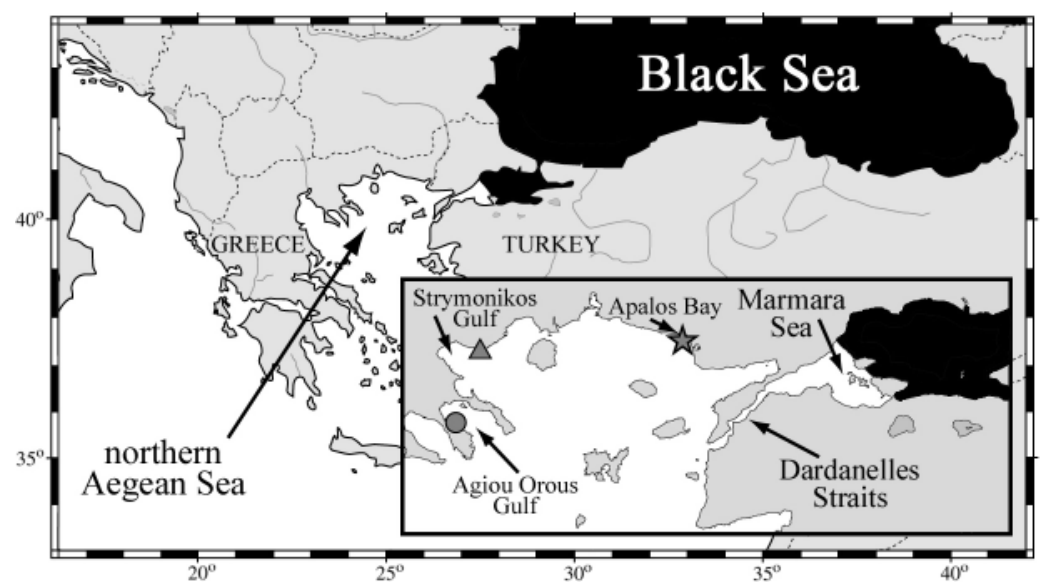

Fig. 1. Phocoena phocoena. Map showing distribution in Black and Marmara Seas (black areas). Inset indicates location of 4 of the 5 harbour porpoise records from the Mediterranean over the past 2 decades. Symbols refer to locations of the northern Aegean records as described in Table 1: 2 : beachcast porpoises sampled in 2000; $\Delta$ : sighting of 1993; O : live stranding of 1997

analysis was performed using the neighbour-joining algorithm (Saitou \& Nei 1987) and the Tamura-Nei model of evolution (Tamura \& Nei 1993) with a gamma correction $(\alpha=0.5)$. A non-parametric bootstrap (Felsenstein 1985) was performed using 1000 replicates to evaluate the support for certain nodes on the tree, particularly the placement of the northern Aegean Sea samples.

In addition to a skin sample, the total length of each porpoise was measured (Table 1) and teeth were collected from the lower right jaw of each. The age of each porpoise was determined by counting growth layer groups (GLGs) in the decalcified, sectioned and stained teeth according to the methods outlined in Bjørge et al. (1995) and Lockyer (1995b). Each GLG is equivalent to $1 \mathrm{yr}$ growth.

\section{RESULTS AND DISCUSSION}

using standard proteinase $\mathrm{K}$ digestion followed by organic extraction as described in Rosel \& Block (1996). A portion of the mtDNA control region was amplified using the polymerase chain reaction (Saiki et al. 1986) and the oligonucleotides L15824 and H16265 (Rosel et al. 1999a), and the resultant PCR products were sequenced in both directions following protocols outlined in Rosel et al. (1999a). DNA sequences were edited using the Sequence Navigator software (ABI) and a consensus sequence created from the forward and reverse reads of each PCR product.

The DNA sequences obtained for these 2 porpoise samples were aligned with harbour porpoise sequences collected previously from individuals from the Northeast $(n=58)$ and Northwest Atlantic $(n=87)$, the Northeast Pacific $(n=29)$ and the Black Sea $(n=9)$ taken from Rosel et al. (1999a,b) and Tolley et al. (2001). To determine the evolutionary placement of these sequences among the other harbour porpoises, a phylogenetic
The mtDNA sequence obtained from each of the northern Aegean Sea porpoises Phocoena phocoena was identical over 344 base pairs to DNA sequences previously obtained from 8 Black Sea porpoises (Rosel et al. 1995). The phylogenetic analysis indicated that these samples clustered with other Black Sea harbour porpoise haplotypes to the exclusion of porpoises from either side of the Atlantic or the Pacific Oceans (Fig. 2). Bootstrap support for the node which clustered the northern Aegean Sea samples with samples from the Black Sea was high (84\%). These genetic results eliminate the Atlantic Ocean as the source of beachcast porpoises in the northern Aegean Sea while strongly implicating the Black Sea as their source.

Harbour porpoise total length varies significantly in different regions, exceeding $200 \mathrm{~cm}$ in some areas (Read 1999). Black Sea porpoises are known to be smaller than Atlantic animals. Tsalkin (1938), as cited

Table 1. Phocoena phocoena. Date, location and basic data of all confirmed harbour porpoise records for the Mediterranean Sea. na: not applicable

\begin{tabular}{|lllcc|}
\hline Date & \multicolumn{1}{c}{ Location } & Type of record & Sex & $\begin{array}{c}\text { Total length } \\
(\mathrm{cm})\end{array}$ \\
\hline 22 Oct 1981 & Playa de la Malagueta, Málaga, Spain & Beachcast & Female & 169 \\
Jan 1993 & Strymonikos Gulf, northern Aegean, Greece & Sighting & na & na \\
26 Jun 1997 & Agiou Orous Gulf, northern Aegean, Greece & Live stranding & Female & Male \\
9 Feb 2000 & Apalos Bay, northern Aegean, Greece & Beachcast & Male & 126 \\
19 Mar 2000 & Apalos Bay, northern Aegean, Greece & Beachcast & & 113 \\
\hline
\end{tabular}




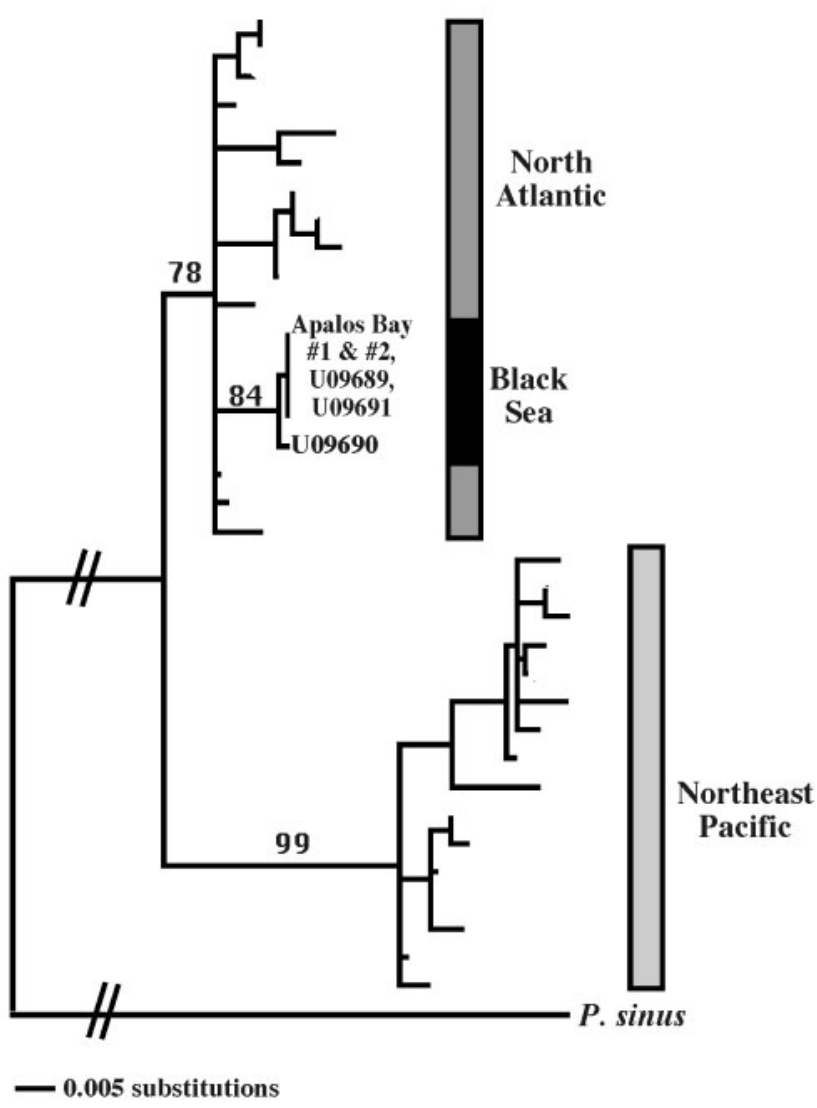

Fig. 2. Phocoena phocoena. Bootstrap neighbour-joining tree (1000 replicates) showing placement of sequences from 2 porpoises collected in Apalos Bay among porpoise haplotypes from the Atlantic, the Black Sea and the Northeast Pacific. Accession nos. U09689 to U09691 are from previously published Black Sea porpoise sequences. Note that U06989 and U09691 are both identical to the 2 Apalos Bay individuals, but differ from each other at a sequence position outside that used in this analysis. Numbers above branches indicate bootstrap support for the major oceanic clades. Outgroup species used was Phocoena sinus

in Tomilin (1967), recorded average lengths of 141.5 and $148.5 \mathrm{~cm}$ for sexually mature adult males and females, respectively. More recently, Gol'din (2000) reported asymptotic lengths of 127 to $146 \mathrm{~cm}$ $(134.4 \pm 5.8 \mathrm{~cm})$ for females and 117 to $152 \mathrm{~cm}$ (mean $126.2 \pm 10 \mathrm{~cm}$ ) for males. This compares to asymptotic lengths of 153 to $163 \mathrm{~cm}$ and 141 to $149 \mathrm{~cm}$ for adult female and male harbour porpoises, respectively, from the North Atlantic (Lockyer 2003). Despite its small size $(126 \mathrm{~cm})$, the teeth from the larger male found in Apalo Bay were curved, and characteristic of an older individual with much dentine and cementum (Bjørge et al. 1995). This male specimen was 13 to 14 yr old based on GLG analysis of the teeth (Fig. 3). A harbour porpoise of comparable length from the Northeast Atlantic would be about 1 or 2 yr old (Lockyer 1995a, Lockyer et al. 2003). The smaller male $(113 \mathrm{~cm})$ was aged at $1 \mathrm{yr}$ old, in line with recent estimates of $1 \mathrm{yr}$ old Black Sea porpoises (both sexes) having a mean length of $109.4 \pm 3.6 \mathrm{~cm}$ (Gol'din 2000). A 1 yr old male from the Northeast Atlantic would normally be expected to be larger than this (Lockyer 1995a, Lockyer et al. 2003).

This striking difference between total length and age supports the genetic analysis, further suggesting that these porpoises are most closely related to those found in the Black Sea. While we cannot rule out the possibility that they represent a small isolated population in the northern Aegean Sea, if such an isolated population does exist then we would expect these porpoises to have a unique genetic signature. Granted only 2 samples have been examined to date, it is most parsimonious to conclude at this time that these animals came from the Black Sea. Genetic analyses of any future beachcast porpoises would help document the phenomenon further.

These results are the first to indicate the probable movement of porpoises out of the Black Sea and into the Mediterranean and raise the question of why Black Sea harbour porpoises have 'suddenly' been appearing along the northern Aegean Sea coast. The waters of the Black Sea are cooler and significantly less saline than Mediterranean waters. However, the northern Aegean Sea is generally cooler and less saline than other regions of the Mediterranean basin due to an influx of Black Sea water (Poulos et al. 1997). The Sea of Marmara and the Bosporus and Dardanelles Straits serve as a conduit between the Black and Aegean Seas. Water flow at the surface is from the Black Sea into the Aegean (Poulos et al. 1997). These characteristics suggest that if porpoises were to leave the Black Sea, the conditions in the northern Aegean Sea (as compared to other parts of the Mediterranean) would be similar to those of the Black Sea, particularly in February and March (Poulos et al. 1997), the months in which these 2 porpoises were collected. Öztürk \& Öztürk (1997) reported the presence of harbour porpoises in both the Bosporus and the Sea of Marmara, further indicating that movement of porpoises between the Black Sea and the Aegean Sea is possible. It is certainly possible that porpoises have occasionally made excursions into the Aegean Sea and that increased effort in stranding networks and public awareness of marine mammals in the Mediterranean has led to improved reporting and recovery of beachcast marine mammals in this region over the last 2 decades.

The Black Sea ecosystem has undergone drastic changes over the past century. Decreased freshwater input due to damming and irrigation of its major 
Fig. 3. Phocoena phocoena. Decalcified thin $(25 \mu \mathrm{m})$ haematoxylin-stained section of a tooth from $126 \mathrm{~cm}$ male porpoise, through midline from crown to root, showing successive growth layer groups (numbered) and other baseline reference features in the tooth

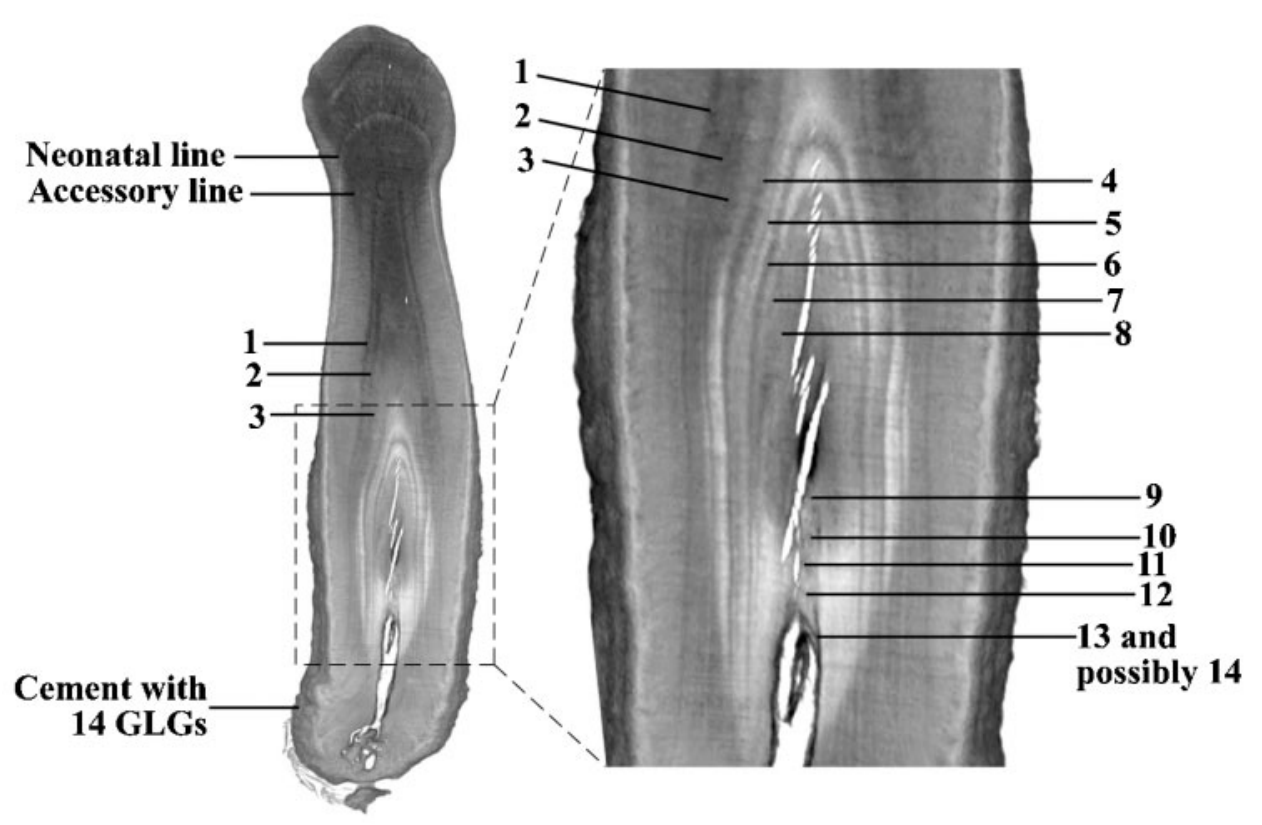

rivers, and increased inputs of organic materials, pollutants, and invasive non-native species have all contributed to the degradation of this unique sea (Bologa 2001). More important perhaps for marine mammals is the change in fish biodiversity and biomass. Overfishing has led to a significant decline in many commercially important species. Both anchovy and mackerel stocks have declined significantly, the latter species being at least commercially extinct since the late 1960s (Bologa 2001). It is interesting that Tomilin (1967) reported that Black Sea porpoises once made migrations into the Sea of Azov during the spring following large schools of anchovies. Is it possible that porpoises are searching over wider ranges for a similar food source? Admittedly this is pure speculation, but it does warrant further investigation, as habitat loss and degradation both play a significant role in the loss of species diversity, and Black Sea harbour porpoises represent a unique genetic component worthy of conservation.

Acknowledgements. We wish to thank the port police authorities of Alexandroupolis, and especially Mr. Nikolaos Aslanidis, for informing us of the 2 harbour porpoise strandings in the North Aegean Sea and for helping in shipping one of them to Athens. The manuscript was improved by comments from 4 anonymous reviewers.

\section{LITERATURE CITED}

Bjørge A, Hohn AA, Kvam T, Lockyer C, Schweder T, Aarefjord $H$ (1995) Report of the harbour porpoise age determination workshop, Oslo, 21-23 May 1990. Rep Int Whal Comm Spec Issue 16:477-496
Bologa AS (2001) Recent changes in the Black Sea ecosystem. In: Borgese EM, Chircop A, McConnell M (eds) Ocean yearbook 15. The University of Chicago Press, Chicago, IL, p 463-474

Felsenstein J (1985) Confidence limits on phylogenies: an approach using the bootstrap. Evolution 39:783-791

Frantzis A, Gordon J, Hassidis G, Komenou A (2001) The enigma of harbor porpoise presence in the Mediterranean Sea. Mar Mamm Sci 17:937-943

Gol'din PE (2000) Age and growth of harbour porpoises (Phocoena phocoena relicta) from the Black Sea and Sea of Azov. Eur Res Cetaceans 14:247-252

Kleinenberg SE (1956) Mammals of the Black Sea and Sea of Azov. Results of joint biological-commercial dolphin whaling studies. USSR Academy of Sciences Press, Moscow

Lockyer C (1995a) Investigation of aspects of the life history of the harbour porpoise, Phocoena phocoena, in British waters. Rep Int Whal Comm Spec Issue 16:189-209

Lockyer C (1995b) A review of factors involved in zonation in odontocete teeth, and an investigation of the likely impact of environmental factors and major life events on harbour porpoise tooth structure. Rep Int Whal Comm Spec Issue 16:511-529

Lockyer C (2003) Harbour porpoises, Phocoena phocoena L., in the North Atlantic: biological parameters. NAMMCO Scientific Publications. North Atlantic Marine Mammal Commission, Tromsø (in press)

Lockyer C, Desportes G, Anderson K, Labberté S, Siebert U (2003) Monitoring growth and energy utilisation of harbour porpoise in human care. NAMMCO Scientific Publications. North Atlantic Marine Mammal Commission, Tromsø (in press)

Öztürk B, Öztürk AA (1997) Preliminary study on dolphin occurrence in the Turkish Straits system. In: Evans PGH, Parsons ECM, Clark SL (eds) Proceedings of the Eleventh Annual Conference of the European Cetacean Society. European Cetacean Society, Kiel, p 79-82

Poulos SE, Drakopoulos PG, Collins MB (1997) Seasonal variability in sea surface oceanographic conditions in the Aegean Sea (Eastern Mediterranean): an overview. J Mar Syst 13:1225-1244 
Read AJ (1999) Harbour porpoise Phocoena phocoena (Linnaeus, 1758). In: Ridgway SH, Harrison R (eds) Handbook of marine mammals, Vol 6. The second book of dolphins and the porpoises. Academic Press, San Diego, p 323-355

Rosel PE, Block BA (1996) Mitochondrial control region variability and global population structure in the swordfish, Xiphias gladius. Mar Biol 125:11-22

Rosel PE, Dizon AE, Haygood MG (1995) Variability of the mitochondrial control region in populations of the harbour porpoise, Phocoena phocoena, on interoceanic and regional scales. Can J Fish Aquat Sci 52:1210-1219

Rosel PE, France SC, Wang JY, Kocher TD (1999a) Genetic structure of harbour porpoise, Phocoena phocoena, populations in the Northwest Atlantic based on mitochondrial and nuclear markers. Mol Ecol 8:S41-S54

Rosel PE, Tiedemann R, Walton M (1999b) Genetic evidence for restricted trans-Atlantic movements of the harbor porpoise Phocoena phocoena. Mar Biol 133:583-591

Editorial responsibility: Otto Kinne (Editor),

Oldendorf/Luhe, Germany
Saiki RK, Bugawan TL, Horn GT, Mullis KB, Erlich HA (1986) Analysis of enzymatically amplified $\beta$-globin and HLA-DQ(alpha) DNA with allele-specific oligonucleotide probes. Nature 324:163-166

Saitou N, Nei M (1987) The neighbor-joining method: a new method for reconstructing phylogenetic trees. Mol Biol Evol 4:406-425

Tamura K, Nei M (1993) Estimation of the number of nucleotide substitutions in the control region of mitochondrial DMA in humans and chimpanzees. Mol Biol Evol 10:512-526

Tolley KA, Vikingsson GA, Rosel PE (2001) Mitochondrial DNA sequence variation and phylogeographic patterns in harbour porpoises Phocoena phocoena from the North Atlantic. Conserv Gen 2:349-361

Tomilin AG (1967) Mammals of the U.S.S.R. and adjacent countries, Vol IX. Israel Program for Scientific Translations, Jerusalem (translated from Russian)

Tsalkin VI (1938) Taxonomy and origin of the porpoise of the Azov and Black Seas. Zool Zh 17:706-733

Submitted: June 12, 2002; Accepted: October 25, 2002

Proofs received from author(s): January 6, 2003 